Ethiopian Journal of Environmental Studies and Management EJESM Vol. 5 no.4 (Suppl.2) 2012

\title{
AN ANALYSIS OF YAM STORAGE STRATEGY TO PROMOTE FOOD SECURITY IN ASA LOCAL GOVERNMENT AREA OF KWARA STATE, NIGERIA

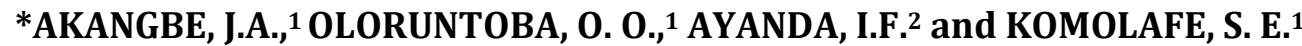

\author{
http://dx.doi.org/10.4314/ejesm.v5i4.S15
}

Received 4th April 2012; accepted 17th October 2012

\begin{abstract}
This study examines the analysis of yam storage strategy to promote food security in Asa Local Government Area of Kwara State, Nigeria. Data was collected from 110 respondents, using wellstructured interviews schedule. The data was analysed using frequency distribution, percentages, means and probit model to test for significance. The study found that barn (47.3\%) and indigenous plant materials (27.3\%) were the common storage strategy used which are not capable of ensuring good storage for yam produce till off season. Probit model analysis revealed that the selected personal characteristics had significant $(p<0.05)$ influence on farmer's choice of strategy used. Deterioration of yam that reduces its quality (mean score 2.01) has also been the leading problem faced in marketing yam produce. It was concluded that these are one of the major reasons for food insecurity among farmers in the study area. It was recommended that farmers should be provided with information regarding improved storage strategies as well as exposed to training on their use.
\end{abstract}

\section{Introduction}

Yam is a valuable source of carbohydrate to the people of the tropical and subtropical Africa, Central and Southern America, parts of Asia, the Caribbean and Pacific Islands (Coursey, 1967). Yams are one of the most highly regarded food products in tropical countries of West Africa and are closely integrated into social, economic, cultural and religious aspects of communities (Okigbo and Ogbonnaya, 2006). Nigeria is known to be the largest producer of yam in the world. Annual production of yam in the country is estimated at 36,720 million metric tonnes of total world's yam production (FAO 2006). The major yam producing states in Nigeria are Adamawa, Benue, Cross River, Delta, Edo, Ekiti, Imo, Kaduna, Kwara, Ogun, Ondo, Osun, Oyo, and Plateau (Akanji et al., 2003).

Yam is very important in food security and poverty reduction in Nigeria, as it is consumed in a variety of ways. The most common in southern and central parts of the country is boiled or pounded yam. It can be cut into chips, dried, and ground into yam flour and prepared as amala which is another delicacy in the Nigerian diet, particularly among the Yoruba of southwestern Nigeria. Yam production serves as a source of income generation to peasant farmers and the laborers who work on yam farms as well as for those that engage in its sale, the itinerant traders who assemble the crop from village to village, and the urban center marketers who retail the commodity. Peelings and waste from yam are often used for feeding poultry and livestock. According to Komolafe et al. (1983), the various uses to which yam is put tends to indicate that the crop is a famine fighter.

In Nigeria, the growth and production of food crop is seasonal, most crops are grown in the rainy season and harvested towards the end the season. And so, food crop are abundant at the end of harvest but scarce a few months after due to poor post-harvest storage system among farmers. Storage of yam poses a problem during the peak harvest period, since it is a tuber crop. The difficulty in storage raises the problems of farmers benefiting from the incidence of seasonal price increases for yam. Yam in the country is also becoming expensive and relatively unaffordable in urban areas as production has not kept pace with population growth leading to demand exceeding supply (Kushwaha and Polycarp, 2001). Because of farmer's poor storability, farmers sell produce just after harvest to avoid losses, and this result in low income or reduced profits. This practice also affects farmers' food security particularly in the lean season.

The Food and Agriculture Organisation states that 'food security at the individual, household, national and global level ... exist when all people at all times, have physical and economic access to sufficient, safe and nutritious food to meet their dietary needs and food preferences for an active and healthy life (FAO, 2006). 
There are several constraints to the yam industry in the country. Of these constraints, diseases contribute greatly to high yield losses before and after harvest. Yam plants are prone to infection by fungi, bacteria, and viruses at all stages of growth and also during storage of tubers. Rot is a major factor limiting the postharvest life of yams and losses can be very high. Losses due to post-harvest rot significantly affect farmers' and traders' income, food security and seed yams stored for planting. The quality of yam tubers are affected by rots, which makes them unappealing to consumers. Most rots of yam tubers are caused by pathogenic fungi such as Aspergillus flavus, Aspergillus niger, Botryodiplodia theobromae, Fusarium oxysporum, Fusarium solani, Penicillium chrysogenum, Rhizoctonia spp., Penicillium oxalicum, Trichoderma viride and Rhizopus nodosus (Okigbo and Ikediugwu, 2002; Aidoo, 2007).

Post-harvest food losses are one of the important sources of food insecurity in Africa. According to AMCOST (2006), pre- and postharvest food crop loss among African countries is estimated at about $10 \%$, which is higher than the global average. Tropical root and tuber crops such as cassava, yam, and cocoyam are important household food security and income generating crops in many African countries (AMCOST 2006; FAO 1998), and over 5 million people are said to depend on these crops for food, feeds and income. Thus, losses associated with these crops limit the potential income of the farmers, threaten food security and exacerbate conditions of poverty among rural households, whose income stream depends on the ability to store excess farm produce for a later date (Thamaga-Chitja et al., 2000).

Yams losses due to rots as a result of poor storage strategy affect its availability, food security and revenue of farmers and traders. These however pose a serious research questions to mind, that need to be visited with kin interest. The questions are: What methods may be used at yam storage strategy? How frequent are the strategies used? What quantity of yams is stored by the farmers? How are the stored products marketed? And what personal characteristics of the farmers may have impact on the study? To solve the problem of food insecurity, there will be need to improve or develop new storage strategy. It is therefore imperative to examine yam storage strategy practiced by farmers in the study area.

\section{Objective of the study}

The study examined the storage strategies used by farmers in Asa Local Government Area (LGA) of Kwara State, Nigeria. Specifically, this study looked at the following objectives, which are to:

i. determine the various methods of yam storage strategy.

ii. investigate the frequency of use of the strategy,

iii. investigate the quantity of yam stored,

iv. investigate marketing of the stored product,

v. determine personal characteristics of farmers in the study area.

\section{Hypothesis of the Study}

The following null hypothesis was tested:

Ho1: There is no significant difference between the farmer's selected personal characteristics and storage strategy used.

\section{Methodology \\ Study Area}

The study was conducted in Asa Local Government Area (LGA) of Kwara State, Nigeria. The LGA was created in 1976 with three (3) districts: Afon, Onire and Owode. The LGA has an area of approximately 103.3 hectares of land and shares boundaries with Moro, Ilorin South, Ifelodun, Oyun LGAs and Oyo state. It has a projected population of about 164,157 people according to census (1998) projection. The people are predominantly Yorubas but spies with Hausas and Fulani settlers. The area is guinea savannah vegetation. Rainfall is between March and October with peak between June and September. The major crop grown are yams, cassava, guinea corn and maize.

The population of the study comprise of all farmers in Asa LGA. A random sampling technique was used to 8 villages. The selected villages are; Alapa, Kondoro, Okoh, Pete, Mandele, Lamba and Alagogo. A total of 110 respondents were used for the study.

Data in this study were obtained from both the primary and secondary sources. The main instrument used for data used for collecting primary data in the study was a well-structured interview schedule with the help of Trained enumerators were used to assist the researcher in conducting the interview. The secondary sources of data used for this study include annual reports and articles whether published and unpublished. 


\section{Data Analysis}

Descriptive analysis such as frequencies, percentages and means were used to analysis data collected. Also probit analysis was used to determine the direction and the magnitude relationship between dependent and independent variables used to test the hypothesis of the study. The probit probability model is associated with the commulative normal probability function. The most common variable used in modelling technique adoption processes are independent variable (Feder at al., 1995). To understand this model, assume there exist a theoretical continuous index $\mathrm{Zi}$ which is determined by an explanary variable $\mathrm{X}$. thus, we can write.

$$
\mathrm{Zi}=\alpha+\beta \mathrm{xi}
$$

Observation on $\mathrm{Zi}$ are not available. Instead, we have data that distinquish only whether individual observations are in one category (high value of $\mathrm{Zi}$ ) or a second category (low value of $\mathrm{Zi})$. Probit analysis solve the problem of how to obtain estimates for the parameters $a$ and $B$, while at the same time obtaining information about the underlining index $\mathrm{Z}$.

Then the probit model provide a suitable means of estimating the slope and intercept parameters of the relationship between the strategy of storage, quantity of yam produced and selected personal characteristics of farmers.
The probit model assume that $\mathrm{Zi}$ is a normally distributed random variable, so that the probability that $\mathrm{Zi}$ is less than (or equal to) $\mathrm{Zi}$ can be computed from the commulatve normal function which is written as:

$\mathrm{pi}=\mathrm{F}(\mathrm{Zi})=\frac{1}{\sqrt{2}} \quad \int^{\mathrm{Zi}} \mathrm{e}^{-\mathrm{s} 2 / 2} \delta \mathrm{s}$.

where $\mathrm{S}$ is a random variable, which is normally distributed with mean Zero and unit variance. By construction, The Pi will lie in the 0.1 interval. Pi represent the probability that an event occurs, in this case the probability is measured by the area under the standard normal curve from $-\infty$ to $\mathrm{Zi}$. The event will be more likely to occur the larger the value of the index $\mathrm{Zi}$.

A probit model can be expressed as:

$\mathrm{Q}=\mathrm{F}(\mathrm{X}, \beta+\mathrm{ei})$ where

$\mathrm{Q}=$ methods and quantity

$\mathrm{B}=$ Vector of respective parameters

ei $=$ independent distribution error term

$\mathrm{X} 1=$ Gender

$\mathrm{X} 2=$ marital status

$\mathrm{X} 3=$ No of children

$\mathrm{X} 4=$ No of wives

$\mathrm{X} 5=$ No of respondent

$\mathrm{X} 6=$ Level of education

$\mathrm{X} 7=$ Secondary occupation

$\mathrm{X} 8=$ Farm size

(Agunor et al., 2001)

\section{Results and Discusion}

Table 1 Personal characteristics of respondents. $(\mathrm{N}=110)$

\begin{tabular}{|l|l|l|}
\hline characteristics & Frequency & Percentage \\
\hline Gender & & \\
Male & 80 & 72.7 \\
Female & 30 & 27.3 \\
\hline Marital status & & \\
Single & 12 & 10.9 \\
Married & 77 & 70.0 \\
Divorce & 11 & 10.0 \\
Widow & 10 & 9.1 \\
\hline No of children & & \\
$1-8$ & 86 & 78.2 \\
$9-16$ & 20 & 18.2 \\
$17-26$ & 4 & 3.6 \\
\hline No of wives & & \\
1 & 69 & 62.8 \\
2 & 25 & 22.7 \\
3 & 14 & 12.7 \\
4 & 2 & 1.8 \\
\hline No of dependents & & \\
$4-10$ & 7 & 70 \\
$11-25$ & 3 & 30 \\
\hline Age & 1 & 0.9 \\
$<20$ & 28 & 25.3 \\
\hline $21-35$ & & \\
\hline
\end{tabular}




\begin{tabular}{|l|l|l|}
\hline $35-50$ & 61 & 55.6 \\
$51-65$ & 20 & 18.2 \\
\hline Level of education & & \\
No formal education & 14 & 12.7 \\
Quranic education & 39 & 35.5 \\
Primary education & 12 & 10.9 \\
Secondary education & 14 & 12.7 \\
OND/NCE & 29 & 26.4 \\
HND/BSC & 2 & 1.8 \\
\hline Farm size & & \\
$<1$ ha & 46 & 41.8 \\
$2-6$ ha & 50 & 45.5 \\
$7-11$ ha & 10 & 9.1 \\
$12-16$ ha & 4 & 3.6 \\
\hline Total & 110 & 100 \\
\hline
\end{tabular}

Data analysis presented in table 1 revealed that $80(72.7 \%)$ of farmers were male while $30(27.3 \%)$ were female. Majority $77(70 \%)$ of the respondents in table 1 were married while 12 $(10.9 \%)$ were not. $11(10 \%)$ and $10(9.1 \%)$ were divorce and widow respectively. Majority 86 (78.2\%) of the respondents had about 8 children, while $4(36 \%)$ had $17-26$ children. The average family size is $8-9$. Over half of the respondents $69(62.8 \%)$ had 1 wife while only $2(1.8 \%)$ had 4 wives. $7(70 \%)$ of the respondents had $4-10$ dependents while 3 (30\%) had $11-25$ dependents. More than half $61(55.6 \%)$ of the respondents fall within the modal age of $36-50$ years.

Findings in the study showed that the farmers attained a very poor level of education especially in the area of formal education $14(12.7 \%)$. This might be as a result of many of them helping their parents from youth and maintaining the work till adulthood. Any level of education, no matter how small, will not only assist in raising productivity, but will increase farmer's ability to understand and respond to new opportunities and innovations.

Farming as primary occupation accounted for 58(52.8\%). This indicates that more than half of the farmers depend solely on agricultural produce for their livelihood. While trading top the list as secondary occupation other than farming, with about 22(18.2\%) respondents. This finding revealed that agrarian societies are involved in production, processing and marketing of agricultural produce.

Analysis on table 1 describes respondent's size of farmland. The result revealed that $46(41.8 \%)$ of the respondents fall in the modal farm size of $3-6$ ha of farmland. While 4(3.6\%) had $12-16$ ha of farm land.
Analysis on table 2 shows that of the 52 respondents who indicated that they use barn, $37(33.6 \%)$ uses it most often, while the remaining $15(13.6 \%)$ uses it often. Table 2 also reveals that out of the 30 respondents who indicated that they use indigenous plant material, $20(18.2 \%)$ uses it most often while $10(9.1 \%)$ uses it often. Out of 10 respondents that were using thatched - pit roof 7(6.4\%) uses it often while $3(2.7 \%)$. All the users of ventilated store shed $5(4.5 \%)$, evaluated stored shed $8(7.3 \%)$ and open sided store $5(4.5 \%)$ were using it most often.

An analysis of table 2 showed that of the 52 respondents who indicated that they use barn $23(19.1 \%)$ considered it very effective, $18(14.6 \%)$ to be moderately effective while $11(10 \%)$ were indifferent. The analysis further reveals that of the 30 respondents who indicated that they use indigenous plant material, only $5(4.5 \%)$ agreed that the strategy is very effective, $10(9.1 \%)$ also indicated that it is Moderately effective while $15(13.6 \%)$ were indifferent. High percentage being indifferent could that more of their produce still gets spoiled when using this strategy to store their produce. Thatched - roof pit had a total of 10 respondents using it with $7(6.4 \%)$ indicating that it is very effective while $3(2.7 \%)$ said it is moderately effective. Only 5 respondents indicate that they use ventilated store shed. 4(3.6\%) of the respondents showed that the strategy is moderately effective while $1(0.9 \%)$ response was indifferent. All the respondents $8(6.4 \%)$ who use elevated store shed indicated that the strategy is moderately effective. $4(3.6 \%)$ out of the total of 5 respondents who uses Open sided store indicated that the strategy is very effective while the remaining $1(0.9 \%)$ were indifferent. 
Table 2 Distribution of respondents based on effectiveness of strategy, how the method is carried out, frequency of strategy usage and how expensive the strategies are.

\begin{tabular}{|c|c|c|c|c|c|c|}
\hline Strategy & Barn & $\begin{array}{l}\text { Indigenous } \\
\text { plant } \\
\text { material }\end{array}$ & $\begin{array}{l}\text { Thatched - } \\
\text { roof pit }\end{array}$ & $\begin{array}{l}\text { Ventilated } \\
\text { store shed }\end{array}$ & $\begin{array}{l}\text { Evaluated } \\
\text { store shed }\end{array}$ & $\begin{array}{l}\text { Open sided } \\
\text { store }\end{array}$ \\
\hline $\begin{array}{l}\text { usage } \\
\text { Most often } \\
\text { Often } \\
\text { Do not use } \\
\text { Total } \\
\text { Mean } \\
\end{array}$ & $\begin{array}{l}37(33.6 \%) \\
15(13.6 \%) \\
58(52.7 \%) \\
179 \\
1.81\end{array}$ & $\begin{array}{l}20(18.2 \%) \\
10(9.1 \%) \\
80(72.7 \%) \\
160 \\
1.45\end{array}$ & $\begin{array}{l}7(6.4 \%) \\
3(2.7 \%) \\
100(90.9 \%) \\
127 \\
1.16 \\
\end{array}$ & $\begin{array}{l}5(4.5 \%) \\
0 \\
105(95.5 \%) \\
120 \\
1.09 \\
\end{array}$ & $\begin{array}{l}8(7.3 \%) \\
0 \\
102(92.7 \%) \\
126 \\
1.15 \\
\end{array}$ & $\begin{array}{l}5(4.5 \%) \\
0 \\
105(95.5 \%) \\
120 \\
1.09\end{array}$ \\
\hline $\begin{array}{l}\text { Effectiveness } \\
\text { V. effective } \\
\text { M. effective } \\
\text { I can't say } \\
\text { I don't use } \\
\text { Total } \\
\text { Mean }\end{array}$ & $\begin{array}{l}23(19.1 \%) \\
18(14.6 \%) \\
11(10 \%) \\
58(52.7 \%) \\
226 \\
2.05\end{array}$ & $\begin{array}{l}5(4.5 \%) \\
10(9.1 \%) \\
15(13.6 \%) \\
80(72.7 \%) \\
160 \\
1.45\end{array}$ & $\begin{array}{l}7(6.4 \%) \\
3(2.7 \%) \\
0 \\
100(90.9 \%) \\
137 \\
1.25\end{array}$ & $\begin{array}{l}0 \\
4(3.6 \%) \\
1(0.9 \%) \\
105(95.5 \%) \\
119 \\
1.08\end{array}$ & $\begin{array}{l}0 \\
8(6.4 \%) \\
0 \\
102(92.7 \%) \\
126 \\
1.15\end{array}$ & $\begin{array}{l}4(3.6 \%) \\
0 \\
1(0.9 \%) \\
105(95.5 \%) \\
123 \\
1.12\end{array}$ \\
\hline $\begin{array}{l}\text { Method } \\
\text { By expert } \\
\text { by self } \\
\text { Do not use } \\
\text { Total } \\
\text { Mean }\end{array}$ & $\begin{array}{l}12(10.9 \%) \\
40(36.4 \%) \\
58(52.7 \%) \\
174 \\
1.58\end{array}$ & $\begin{array}{l}0 \\
30(27.3 \%) \\
80(72.7 \%) \\
140 \\
1.27\end{array}$ & $\begin{array}{l}3(2.7 \%) \\
7(6.4 \%) \\
100(90.9 \%) \\
123 \\
1.12\end{array}$ & $\begin{array}{l}5(4.5 \%) \\
0 \\
105(95.5 \%) \\
120 \\
1.09\end{array}$ & $\begin{array}{l}6(5.5 \%) \\
2(1.8 \%) \\
102(92.7 \%) \\
124 \\
1.13\end{array}$ & $\begin{array}{l}5(4.5 \%) \\
0 \\
105(95.5 \%) \\
120 \\
1.09\end{array}$ \\
\hline $\begin{array}{l}\text { expensiveness } \\
\text { V. expensive } \\
\text { M. expensive } \\
\text { Not expensive } \\
\text { do not know } \\
\text { Total } \\
\text { Mean }\end{array}$ & $\begin{array}{l}5(4.5 \%) \\
15(13.6 \%) \\
32(29.1 \%) \\
58(52.7 \%) \\
187 \\
1.70 \\
\end{array}$ & $\begin{array}{l}7(6.4 \%) \\
4(3.6 \%) \\
19(17.3 \%) \\
80(72.7 \%) \\
158 \\
1.45 \\
\end{array}$ & $\begin{array}{l}0 \\
5(4.5 \%) \\
5(4.5 \%) \\
100(90.9 \%) \\
125 \\
1.14 \\
\end{array}$ & $\begin{array}{l}4(3.6 \%) \\
1(0.9 \%) \\
0 \\
105(95.5 \%) \\
124 \\
1.13 \\
\end{array}$ & $\begin{array}{l}0 \\
4(3.6 \%) \\
4(3.6 \%) \\
102(92.7 \%) \\
122 \\
1.11 \\
\end{array}$ & $\begin{array}{l}3(2.7 \%) \\
0 \\
2(1.8 \%) \\
105(95.5 \%) \\
121 \\
1.10 \\
\end{array}$ \\
\hline
\end{tabular}

Data analysis on table 2 revealed that of the 52 respondents who uses barn, 12(10.9\%) employ experts while $40(36.4 \%)$ do it themselves. The analysis also reveals that of the 30 respondents who indicated that they use indigenous plant material, all of them do by themselves. With 10 respondents using thatched - roof pit, $3(2.7 \%)$ employ expert to carry out the strategy while $7(6.4 \%)$ do it by themselves. All the 5(4.5\%) of respondents who use ventilated store shed employ expert to carry out the strategy. Out of the 8 respondents who indicated that they use evaluated store shed, $6(5.5 \%)$ of them employ expert while $2(1.8 \%)$ do it by themselves. All the 5(4.5\%) respondents who indicated that they use Open sided store employ expert to carry out the strategy.

Data analysis on table 2 shows that of respondents who uses barn, 5(4.5\%) indicated that it is very expensive, $15(13.6 \%)$ indicated that it is moderately expensive while $32(29.1 \%)$ indicated that barn is not expensive. The high percentage of respondents who claimed that barn is not expensive might be the reason for it high usage since moderately high percentage had also indicated that the strategy was very effective and most effective.

The results also shows that of the 30 respondents who indicated that they use indigenous plant material, 7(6.4\%) indicated that the strategy is very expensive, 4(3.6\%) also indicated that it is moderately expensive while $19(17.3 \%)$ indicated that the strategy is not expensive. The low cost of indigenous plants materials does not automatically result to it high usage because only few percentage had considered it to be very effective.

Results from table 2 further shows that of the 10 respondents that uses thatched - pit roof, $5(4.5 \%)$ considered it to very expensive 
while $5(4.5 \%)$ indicated that it is moderately expensive. Results from table 2 also revealed that of the 5 respondents that uses ventilated store shed, $4(3.6 \%)$ indicated that the strategy is very expensive while $1(0.9 \%)$ considered it to be moderately expensive. 4 out of 5 respondents that indicated ventilated store shed to be very expensive might be because all of them have indicated that it requires them to employ expert and so, high percentage 105(95.5\%) were not using the strategy even though the few percentage that were using it indicated that the strategy is moderately effective.

Out of the 8 respondents who indicated that they use evaluated store shed, 4(3.6\%) indicated that the strategy is moderately expensive while $4(3.6 \%)$ considered it not to be expensive. 6 out 8 respondents who uses It had indicated that it requires them to employ expert, the cost of employing expert might be the reason it had been considered to be moderately expensive and for low usage despite the fact that the few percentage that were using the strategy have considered it moderately effective.

Results from table 2 revealed that among respondents who uses open sided store, $3(2.7 \%)$ indicated that it is very expensive while $2(1.8 \%)$ indicated that it is not expensive. This might be because they have indicated that the strategy requires them to employ expert but very few percentage of the total respondents were using it despite it fact that all the few percentage that were using it considered it to be very effective.

Table 3 Distribution of respondents based on methods of yam storage, quantity of yam produced, quantity of yam stored and what determine when they sell their produce.

\begin{tabular}{|l|l|l|}
\hline & Frequency & Percentage \\
\hline Method of yam storage & & \\
Barn & 52 & 47.3 \\
Indigenous plant material & 30 & 27.3 \\
Thatched - roof pit & 10 & 9.1 \\
Ventilated store shed & 5 & 4.5 \\
Evaluated store shed & 8 & 7.3 \\
Open sided store & 5 & 4.5 \\
\hline Quantity of yam produce (kg) & & \\
$600-4000$ & 76 & 69.4 \\
$400-7401$ & 13 & 11.4 \\
$7402-10802$ & 7 & 6.3 \\
$10803-14203$ & 4 & 3.7 \\
$14204-17604$ & 4 & 3.7 \\
$17605-21009$ & 6 & 5.5 \\
\hline Quantity of yam stored (kg) & & \\
$300-2050$ & 47 & 42.8 \\
$2051-3801$ & 31 & 28.2 \\
$3802-5552$ & 8 & 7.3 \\
5553-7303 & 8 & 7.3 \\
$7304-9054$ & 8 & 7.3 \\
$9055-10804$ & 8 & 7.3 \\
\hline What determine when they sell & & \\
their produce & 41 & 37.3 \\
Festival & 26 & 23.6 \\
Long storage & 25 & 22.7 \\
Market price & 18 & 16.4 \\
During planting & & \\
\hline & & \\
\hline
\end{tabular}


Results from table 3 revealed that 52 $(47.3 \%)$ of the respondents used barn, $30(27.3 \%)$ used indigenous plant materials while $5(4.5 \%)$ used ventilated pit store and open side shelves respectively. There exist some other storage methods like cool storage and gamma radiation but farmers in the study are not familiar with them. A total of 45 $(40.9 \%)$ said they got to know about the storage strategies from their parents, while only 15 (13.6\%)got to know about them through extension agents.

Data from table 3 shows that majority 76 $(69.4 \%)$ produce between $600-4000 \mathrm{~kg}$ of yam tubers, $13(11.4 \%)$ produced between 2051 - 3801kg per annum while others produced less than $2051 \mathrm{~kg}$ of tubers per annum.

Results from table 3 shows that majority $47(42.8 \%)$ stored between $300-2050 \mathrm{~kg}$ of yam tuber per annum. The results on table 3 reveals that produce are sold more during festivals where $41(37.3 \%)$ asserted to this fact. This could be due to the ready market during this period. $18(16.4 \%)$ indicated that produce sell more during planting season.

Table 4 Distribution of respondents based on problems faced in the marketing of produce.

\begin{tabular}{|c|c|c|c|c|c|c|}
\hline Problems & $\begin{array}{l}\text { Most } \\
\text { severe }\end{array}$ & Severe & $\begin{array}{l}\text { Less } \\
\text { severe }\end{array}$ & $\begin{array}{l}\text { Total } \\
\text { score }\end{array}$ & Mean score & Rank \\
\hline $\begin{array}{l}\text { Some of the produce get } \\
\text { spoilt }\end{array}$ & 41 & 25 & 44 & 217 & 1.97 & $3^{\text {rd }}$ \\
\hline $\begin{array}{l}\text { Poor quality at the time of } \\
\text { sales as a result of } \\
\text { deterioration. }\end{array}$ & 36 & 39 & 35 & 221 & 2.01 & $1^{\mathrm{st}}$ \\
\hline Transportation & 30 & 37 & 43 & 207 & 1.88 & $5^{\text {th }}$ \\
\hline Market distance from farm & 35 & 38 & 37 & 218 & 1.98 & $2^{\text {nd }}$ \\
\hline Poor buyers & 34 & 39 & 37 & 217 & 1.17 & $3^{\text {rd }}$ \\
\hline
\end{tabular}

Analysis on table 4 revealed some of the problems faced in the marketing of produce. The result shows that commodity being sold at cheap rate was ranked first among problems farmers faced in marketing their produce. This may be because of the quality deterioration of yam as a result of poor storage strategy till the time of sales. Transportation ranked the $5^{\text {th }}$ (lowest) with mean score of 1.88 . This could be because yam is an annual crop and the main cause of deterioration which is sprouting and rotting are natural phenomena which even best of storage cannot hinder but can only be delayed. This brings to bear the need for improvement of yam varieties that will not be susceptible to the two natural phenomena.

\section{Test for hypothesis}

Ho1: there is no significant relationship between the farmer's selected personal characteristics and the storage strategy used.

The probit model results presented on table 5 revealed that the number of dependent level of education, secondary occupation, age, gender and farm size were significant at 0.05 significant level to the use of elevated store shed. Age is negatively significant which indicates that only younger respondent's use elevated store shed. Also, gender, number of dependent and secondary occupation were negatively significant which indicates that men use more of Elevated store shed strategy also number of relatives that the fewer the relative living with them the more the possibility of using improved method storage. This may not be unconnected to the fact that tends to produce at subsistence level, producing little hence making use of less expensive method. Level of education is positively significant; this indicates that the higher the level of education the more the likelihood that they tend to use elevated store shed methods of storage and due to their exposure they tend to have the knowledge at their fingertips. Farm size is positively significant which indicate that the larger the farm sizes the likelihood that the respondent will go for elevated store shed strategy. 
An Analysis of Yam Storage Strategy to Promote Food...........Akangbe et al. EJESM Vol. 5 no.4 (Suppl.2) 2012

Table 5 Probit model analysis for hypothesis 1

\begin{tabular}{|c|c|c|c|c|c|c|c|c|}
\hline & \multicolumn{2}{|c|}{ Elevated store shed } & \multicolumn{2}{|c|}{ thatched - roof pit } & \multicolumn{2}{|l|}{ barn } & \multicolumn{2}{|c|}{$\begin{array}{l}\text { indigenous plant } \\
\text { materials }\end{array}$} \\
\hline & coefficient & $\mathrm{t}$-value & coefficient & t-value & coefficient & t-value & coefficient & t-value \\
\hline $\mathrm{X} 1$ & $\begin{array}{l}0.41364 \\
(0.13866)\end{array}$ & $2.98307 *$ & $\begin{array}{l}0.86178 \\
(0.15437)\end{array}$ & $5.58277^{*}$ & $\begin{array}{l}0.14575 \\
(0.45370)\end{array}$ & $3.2122 *$ & $\begin{array}{l}0.12121 \\
(0.04402)\end{array}$ & $-2.75372 *$ \\
\hline $\mathrm{X} 2$ & $\begin{array}{l}-0.06833 \\
(0.10205)\end{array}$ & -0.66958 & $\begin{array}{l}0.22298 \\
(0.09557)\end{array}$ & $2.33327 *$ & $\begin{array}{l}-0.03530 \\
(0.02247)\end{array}$ & $\begin{array}{l}-1.57 \\
089\end{array}$ & $\begin{array}{l}0.01650 \\
(0.21870)\end{array}$ & 0.75432 \\
\hline X3 & $\begin{array}{l}0.01406 \\
(0.02410)\end{array}$ & 0.58340 & $\begin{array}{l}0.08956 \\
(0.02532)\end{array}$ & $3.53722 *$ & $\begin{array}{l}0.22060 \\
(0.01003)\end{array}$ & $2.20008 *$ & $\begin{array}{l}0.01574 \\
(0.00975)\end{array}$ & 1.61493 \\
\hline $\mathrm{X} 4$ & $\begin{array}{l}0.26762 \\
(0.14339)\end{array}$ & 1.86636 & $\begin{array}{l}0.25733 \\
(0.13445)\end{array}$ & 1.91400 & $\begin{array}{l}0.086950 \\
(0.44390)\end{array}$ & 1.95870 & $\begin{array}{l}0.07288 \\
(0.42930)\end{array}$ & 1.69751 \\
\hline $\mathrm{X} 5$ & $\begin{array}{l}-0.09027 \\
(0.03264)\end{array}$ & $-2.76564 *$ & $\begin{array}{l}-0.07022 \\
(0.00804)\end{array}$ & $-8.7391 *$ & $\begin{array}{l}0.01192 \\
(0.07270)\end{array}$ & 1.63988 & $\begin{array}{l}0.00467 \\
(0.00744)\end{array}$ & -0.62806 \\
\hline X6 & $\begin{array}{l}-0.06901 \\
(0.00701)\end{array}$ & $-9.84053 *$ & $\begin{array}{l}-0.03978 \\
(0.06331)\end{array}$ & -0.62839 & $\begin{array}{l}0.02835 \\
(0.00201)\end{array}$ & $14.13179 *$ & $\begin{array}{l}0.24510 \\
(0.00186)\end{array}$ & $13.169 *$ \\
\hline X7 & $\begin{array}{l}0.13580 \\
(0.05320)\end{array}$ & $2.55258^{*}$ & $\begin{array}{l}0.02181 \\
(0.02765)\end{array}$ & 0.78881 & $\begin{array}{l}0.00457 \\
(0.01836)\end{array}$ & 0.24899 & $\begin{array}{l}-0.01019 \\
(0.17680)\end{array}$ & -0.57604 \\
\hline $\mathrm{X} 8$ & $\begin{array}{l}-0.07220 \\
(0.02238)\end{array}$ & $-3.22594^{*}$ & $\begin{array}{l}0.02010 \\
(0.00850)\end{array}$ & $2.36446^{*}$ & $\begin{array}{l}-0.00883 \\
(0.00774)\end{array}$ & -1.14074 & $\begin{array}{l}-0.01591 \\
(0.00751)\end{array}$ & $-2.1196^{*}$ \\
\hline X9 & $\begin{array}{l}0.057280 \\
(0.00802)\end{array}$ & $7.14292 *$ & $\begin{array}{l}0.00373 \\
(0.00039)\end{array}$ & $9.46347 *$ & $\begin{array}{l}0.01147 \\
(0.00314)\end{array}$ & $3.64932 *$ & $\begin{array}{l}0.00098 \\
(0.00843)\end{array}$ & 0.28678 \\
\hline $\begin{array}{l}X \\
10\end{array}$ & $\begin{array}{l}0.00280 \\
(0.00025)\end{array}$ & 4.10780 & & & $\begin{array}{l}0.00034 \\
(0.00080)\end{array}$ & -1.28631 & $\begin{array}{l}0.00034 \\
(0.00080)\end{array}$ & -1.28631 \\
\hline$X^{2}$ & 178228.112 & & 1647.631 & & 1327.59 & & 1554.790 & \\
\hline
\end{tabular}

Source: field survey 2008

Note: $\mathrm{X} 1=$ age, $\mathrm{X} 2=$ Marital status, $\mathrm{X} 3=$ Number of children, $\mathrm{X} 4=$ Number of wives, $\mathrm{X} 5=$ Number of dependant, $\mathrm{X} 6=$ Age, $X 7=$ Level of education, $X 8=$ Secondary occupation, $X 9=$ Farm size, $\mathrm{X} 10=$ Quantity produced. *Significant at the level of $\alpha<0.05$ level.

Results on table 5 also revealed that only gender, marital status, number of children, Age, and secondary occupation are significant to the use of thatched - roof pit. Age is negatively significant which indicates that older respondents use the thatched roof pit strategy. Farm size is positively significant which indicates that the larger the farmers size the more the thatched roof pit strategy. Number of children is positively significant which indicates that as the number of children increases they tend to use more of the thatched roof pit strategy marital status is also positively significant indicates married store and use the thatched roof pit strategy. Gender is positively significant which indicates that male respondents use thatched roof pit strategy.

The results on table 5 shows that only gender, age and secondary occupation are significant and they are all significant at 0.05 level of significance to the use of barn. Gender is positively significant. Number of children is positively significant which indicates that the higher the number of children, the more they use barn to store produce. This could be to the fact that they have more hands to arrange the yam tubers in the barn.

Age of respondents is positively significant which indicates that older respondents use barn store. Farm size is positively significant; this indicates that farmers having large farms use more of barn to store.

The result of the analysis on table 5 reveals that only gender, age and secondary occupation are significant at the level 0.05 level of significant to the use of indigenous plant materials. Gender is negatively significant which indicates that females make use of indigenous plant material. Age is positively significant which indicates that older respondents make use of the strategy. Secondary occupation is negatively significant Ethiopian Journal of Environmental Studies and Management EJ ur uns suatcy.

\section{Conclusion}


Based on the results of this findings, very few of the farmers use modern sophisticated storage strategy, majority are stocked with the use of barn and indigenous plant materials. These common strategies can still not effectively store yam till off season. This had been one of the major causes of food insecurity in the study area despite the bountiful harvest they realize during the growing season.

\section{Recommendation}

In order to enhance better storage strategies among farmers in the study area, the following are recommended:

1. There should be capacity building for all extension functionaries so as to make them highly responsive to the task of disseminating technical information on improved variety and new storage strategy for storing yam.

2. Research institutes should be encouraged to research into ways by which the natural phenomena causing deterioration in yam could be prevented.

\section{References}

Akanji, B.O., Akpokodje, G. and Ogundele, O.O. (2003), Labour use pattern on farms. Pages 34-46 in NISER Annual Survey of Crop Production Condition in Nigeria, 2000. NISER, Ibadan, Nigeria.

Aidoo, K.A. (2007), Identification of yam tuber rot fungi from storage systems at the Kumasi Central market. A dissertation submitted to Faculty of Agriculture, K.N.U.S.T.; 18-19 pp.

AMCOST (2006), Technologies to reduce post-harvest food loss The African Ministerial Council on Science and Technology (AMCOST) of the African Union (AU), Pretoria, South Africa, (2006).

Coursey, D.G. (1967), Yams. Longmans, London. 230pp.
FAO. (2006), Food and Agricultural Organization 2006. Databases. F.A.O. report (1998).

FAO Annual Report. Food and Agriculture Organisation Production Year Book. FAO Rome.

Feder, G., Just, R. E., and Zilberman, D. (1995), Adoption of agricultural innovations in developing countries; A survey Economic Development and Cultural Change. Pp 255 298

Komolafe, M.F., Adegbola, A.A. Are, L.A.and Asheye, T.L. (1983), Agricultural science for West African schools and colleges. 2nd Edition, University Press Limited, Ibadan. Pp 185.

Kushwaha, S. and Polycarp, I.M. (2001), Economics of small scale yam production in Qua' an Pau LGA of Plateau. Pages 69-74 in The role of agriculture in poverty alleviation, edited by M.M. Abubakar, T.A. Adegbola, and I.S.R. Butswat. Proceedings 34th Annual Conference of Agriculture Society of Nigeria, held 15-19 October, 2001, Abubakar Tafawa Balewa University (ATBU), Bauchi, Nigeria.

Okigbo, R.N. and Ikediugwu, F.E.O. (2002), Evaluation of water losses in different regions of yam (Dioscorea spp.) tuber in storage. Nig. J. Exp. Appl Bio 3.320 pp.

Okigbo, R.N. and Ogbonnaya, U.O. (2006), Antifungal effects of two tropical plant extracts (Ocimum gratissimum and Aframomum melegueta) on post-harvest yam rot. African Journal of Biotechnology 5(9), 727-731.

Thamaga-Chitja, J.M., Hendriks, S.L, Ortmann, G.F, Green, M. (2004), Impact of maize storage on rural household food security in Northern Kwazulu-Natal Tydskrif vir Gesinsekologie en Verbruikerswetenskappe, 32, 8-15. 